Reprod. Nutr. Dévelop., 1985, 25 (4 A), 647-657.

\title{
In vivo cholesterol synthesis by the rat digestive tract. I. A topological study
}

\author{
Martine PERRODIN, C. LUTTON
}

Laboratoire de Physiologie de la Nutrition $\left({ }^{1}\right)$, Université de Paris-Sud, Bat. 447, 91405 Orsay Cedex, France.

Summary. Rats were fed a semi-purified diet containing $0.5 \%$ cholesterol ; cholesterogenesis was measured in vivo $70 \mathrm{~min}$ after $\left[1-{ }^{14} \mathrm{C}\right]$-acetate or tritiated water was incorporated into the gastrointestinal tract sterols. The results were qualitatively similar with the two precursors. Cholesterol synthesis was preponderant in the small intestine and mainly occurred in its mucosa with a decreasing biosynthetic gradient from the duodenum to the distal ileum. The gradient of cholesterogenesis decreased from the crypt cells to the apical cells in all segments of the intestine studied.

\section{Introduction.}

Studies carried out in this laboratory and others have shown the importance of cholesterol synthesis in the gastrointestinal tract of the rat, particularly in the small intestine (Chevallier and Lutton, 1973; Andersen and Dietschy, 1979). Certain authors studying local variations in intestinal cholesterogenesis have obtained very diverse results. In a previous in vitro study, Dietschy and Siperstein (1965) demonstrated that $\left[{ }^{14} \mathrm{C}\right]$-acetate incorporation into cholesterol was more efficient in the ileum than in the jejunum. On the contrary, Sugano et al. (1980, 1982) more recently observed that hydroxymethylglutaryl CoA reductase activity was higher in the duodenum and jejunum than in the ileum. However, cholesterol synthesis was generally very high in the proximal intestine before the opening of the common bile duct. For some authors, cholesterogenetic intensity is higher in the crypt cells (Dietschy and Siperstein, 1965 ; Sugano et al., 1982), whereas for others, it is higher in the enterocytes at the top of the villi (Mak and Trier, 1972 ; Merchant and Heller, 1977). Finally, Muroya et al. (1977) found no differences between the two types of cells. These conflicting results could be explained by

(1) UA 646 CNRS, Unité alliée à I'INSERM (Prof. C. Lutton). 
differences in nutritional conditions (sometimes improperly defined), or by the fact that the observers were not always interested in the same part of the small intestine and that the measurements were made with various radioactive precursors and at various times after their administration.

We were therefore interested in carrying out a topological and kinetic study of intestinal cholesterogenesis in vivo under well-defined nutritional conditions. The rats were fed a cholesterol-enriched diet $(0.5 \%)$ in order to reduce the specific activity of plasma cholesterol for a few hours and to minimize the possible contribution of radioactive plasma cholesterol in the enterocytes by cholesterol exchange with plasma or by reabsorption of biliary cholesterol. In order to compare the results we studied two precursors of cholesterol synthesis and monitored the profile of sterol specific radioactivity in the gastrointestinal tract, especially in enterocytes located in different parts of the small intestine and villi, as a function of time ( $70 \mathrm{~min}$ and 8,24 and $48 \mathrm{~h}$ ).

This paper demonstrates that cholesterologenesis decreases in vivo from the first to the last quarter of the small intestine and from the crypt to the apical cells in rats fed a semi-purified diet with $0.5 \%$ cholesterol.

\section{Materials and methods.}

\section{Physiological techniques.}

Animals and diet. - After weaning, male Wistar rats were fed ad libitum the semi-purified diet of the laboratory (Chevallier et al., 1975) which had the following percent composition : saccharose 53 , casein 23 , salts 5 , yeast 2.3 , milk 4 , agar-agar with added vitamins 2.5 , nut oil 0.8 , lard 9.2, cystine 0.2 . When they were 4 months old, the diet was enriched with $0.5 \%$ cholesterol for three weeks. The rats (weight : $350 \pm 30 \mathrm{~g}$ ) were maintained in an animal room with controlled light cycle $(8 \mathrm{~h}-20 \mathrm{~h})$, temperature $\left(24 \pm 1^{\circ} \mathrm{C}\right)$ and hygrometry.

/sotopic experiments. - A total of 13 rats (group A) were killed 70 min and 8,24 or $48 \mathrm{~h}$ after a subcutaneous injection of $\left[1-{ }^{14} \mathrm{C}\right]$-acetate $(200 \mu \mathrm{Ci})$ dissolved in a $0.2-\mathrm{ml}$ physiological saline solution. The sacrifice time was 10 a.m. for those killed $70 \mathrm{~min}$ and 24 and $48 \mathrm{~h}$ after tracer injection and 5 p.m. for those killed $8 \mathrm{~h}$ after injection.

Four rats (group E) received $131 \mathrm{mCi}$ of tritiated water by intravenous injection in the penis vein. They were killed $70 \mathrm{~min}(2 \mathrm{rats})$ and 8 and $24 \mathrm{~h}$ after tracer injection as above. The bile of one $\left(E_{1}^{\prime}\right)$ of the two rats killed at 70 min was collected from 0 to $70 \mathrm{~min}$ to see if bile radioactivity would account for a significant proportion of the intestinal radioactivity.

Organ collection. - The liver, stomach, small intestine and caecum plus the colon were collected following exsanguination and after the circulatory system had been washed several times with saline. The small intestine was divided into four equal quarters. The stomach, small intestine and caecum-colon contents were collected after the walls of the organs had been washed with Weiser 
solution (A) ( $\mathrm{NaCl} 154 \mathrm{mM}$, dithiothreitol $1 \mathrm{mM})$, then with a second solution (B) $\left(\mathrm{NaCl} 96 \mathrm{mM}, \mathrm{KCl} 1.5 \mathrm{mM}\right.$, sodium citrate $27 \mathrm{mM}, \mathrm{KH}_{2} \mathrm{PO}_{4} 8 \mathrm{mM}, \mathrm{Na}_{2} \mathrm{HPO}_{4}$ $5.6 \mathrm{mM}, \mathrm{pH}$ 7.3) for $15 \mathrm{~min}$ in a water bath at $37{ }^{\circ} \mathrm{C}$. Sequential fractions of isolated enterocytes were obtained by a series of incubations and repeated 'washings of gut loops with a third solution (D) $(\mathrm{NaCl} 137 \mathrm{mM}, \mathrm{KCl} 2.69 \mathrm{mM}$, $\mathrm{Na}_{2} \mathrm{HPO}_{4} 8.10 \mathrm{mM}, \mathrm{KH}_{2} \mathrm{PO}_{4} 1.47 \mathrm{mM}$, EDTA $1.5 \mathrm{mM}$, dithiothreitol $0.5 \mathrm{mM}$, $\mathrm{pH} 7.4$ ) at $37^{\circ} \mathrm{C}$. These fractions appeared to define a cell gradient from the top of the villus (fractions 1-3) to the bottom of the villus (fractions 4-6) and to the crypt area (fractions 7-9). In fact, $3 \mathrm{~h}$ after a ${ }^{3} \mathrm{H}$-thymidine intraperitoneal injection, more than $80 \%$ of the DNA radioactivity was found in the cells removed with fractions $7-9$ (crypt cells), while less than $5 \%$ was distributed in fractions 1-3 (top cells).

\section{Chemical and isotopic techniques.}

[1- $\left.{ }^{14} \mathrm{C}\right]$-acetate and $\left[{ }^{3} \mathrm{H}_{2} \mathrm{O}\right]$ were purchased from the CEA (France). Dithiothreitol, Cleland's reagent, was from Sigma. The intestinal cells, walls, red blood cells and plasma lipids were saponified in boiling alcoholic $2 \mathrm{~N} \mathrm{KOH}$ for $2 \mathrm{~h}$. The sterols were extracted with petroleum ether and precipitated with digitonin by the Sperry and Webb (1950) method. After washing, the digitonide complexes were weighed then broken down with pyridine. Cholesterol was purified from its possible labelled precursors by chromatography on alumina gel impregnated with $\mathrm{AgNO}_{3}$ with a chloroform/petroleum ether/acetone mixture $(60 / 30 / 2, \mathrm{v} / \mathrm{v} / \mathrm{v})$ as migrating solvent. Cholesterol was assayed by the Lieberman-Burchard reaction. Radioactivity was measured in a PPO/dimethyl-POPOP/toluene solution with a liquid scintillation spectrometer (MR 300, Kontron) in glass flasks with a low background. DNA was measured as described by Croft and Lubran (1965) and proteins according to Gornall et al. (1949) using bovine serum albumin as a standard.

\section{Results.}

Preliminary experiments. - Preliminary experiments were carried out to determine the sacrifice time after labelled acetate administration. Figure 1 shows the pattern of ${ }^{14} \mathrm{CO}_{2}$ specific activity (reflecting that of the acetate body pool) during the $6 \mathrm{~h}$ after precursor injection. The peak values were reached 30 to $45 \mathrm{~min}$ after the injection. The rapid decrease in ${ }^{14} \mathrm{CO}_{2}$ specific activity $(10$-fold after $2 \mathrm{~h} 30$ and 100-fold after $6 \mathrm{~h}$ ) revealed the high acetate pool turnover. Thus, synthesized cholesterol was considered as strongly marked within a relatively short time after acetate administration. Other preliminary experiments were used to check cholesterol specific activity in the various organs during the first hour after acetate administration. If the cholesterol precursors reached a higher specific activity than the cholesterol during the first minutes, we made sure that at 70 min the specific activity of purified cholesterol was the same as that of the digitoninprecipitable sterols. For these reasons, we chose $70 \mathrm{~min}$ as the earliest time of sacrifice. 


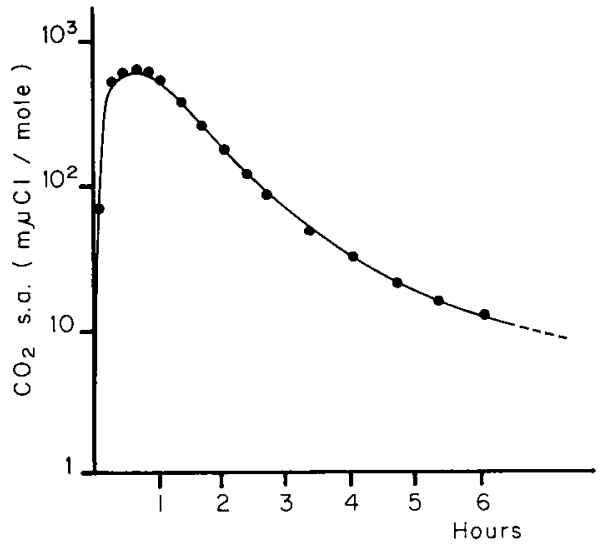

FIG. 1. - Profile of exhaled $\mathrm{CO}_{2}$ specific activity in relation to time in rats receiving a subcutaneous injection of ${ }^{14} \mathrm{C}$ acetate. Mean curve of 6 rats.

Experiments using acetate (group A). - Table 1 shows the total cholesterol radioactivity in the blood, liver and different digestive tract organs 70 min after the labelled precursor was administered in rats fed a cholesterol-enriched diet $(0.5 \%)$. When expressed as a percentage of the total $\left[{ }^{14} \mathrm{C}\right]$-cholesterol recovered in the organs listed in table 1 , less than $1 \%$ was found in red cells and plasma and $3 \%$ in the liver, while almost the total amount $(\geqslant 96 \%)$ was found in the digestive tract, and mainly in the small intestine $(72 \%)$. Distribution in the latter organ was not homogeneous, as $38,32,13$ and $17 \%$ of the total sterol radioactivity in the small intestine was found in the 1st, 2 nd, 3rd and 4th quarters, respectively. More than $90 \%$ of the intestinal cholesterol radioactivity was in the mucosa associated with the enterocytes collected. The mucosa contained approximately $60 \%$ of the small intestine cholesterol. On an average, $85 \%$ of the mucosal cholesterol was collected in the first three quarters of the intestine. The

\section{TABLE 1}

Sterol radioactivity (dpm) in the blood, liver and digestive tract of rats $70 \mathrm{~min}$ after a subcutaneous injection of ${ }^{14} \mathrm{C}$ acetate $(100 \mu \mathrm{Ci})$

\author{
Red Cells* \\ Plasma* \\ Liver \\ Stomach \\ Stomach content \\ Small intestine \\ Intestinal content \\ Caecum + Colon \\ Caecum + colon content
}

$\begin{aligned} & 433 \pm 187^{* *} \pm 190 \\ & 504 \pm 1311 \\ & 2965 \pm 1 \\ & 10525 \pm 1603 \\ & \text { traces } \\ & 79898 \pm 2094 \\ & 3512 \pm 922 \\ & 12453 \pm 2094 \\ & 203 \pm \quad 65\end{aligned}$

* Estimated value for $20 \mathrm{ml}$ of blood (red cells : $8 \mathrm{~g}$, plasma : $12 \mathrm{ml}$ ).

* Mean \pm SEM $(\mathrm{n}=3)$. 
1st, 2nd and 3rd quarters contained $25 \pm 1 \%, 32 \pm 2 \%$ and $28 \pm 2 \%$, respectively, and the 4 th quarter only $15 \pm 1 \%(n=6)$. The relative cholesterol and protein contents of the enterocytes did not vary significantly from the duodenum to the ileum ( $21.8 \pm 0.4 \mu \mathrm{g}$ of cholesterol $/ \mathrm{mg}$ of protein, $\mathrm{n}=6 \times 4$ ). Nevertheless, the quantity of cholesterol or proteins (expressed per mg of DNA) was not as high in the distal ileum enterocytes (4th quarter) $0.43 \pm 0.05 \mathrm{mg}$ of cholesterol and $20.0 \pm 1.0 \mathrm{mg}$ of protein $/ \mathrm{mg}$ of DNA, $n=6$ ) as in the jejunal enterocytes $10.65 \pm 0.01 \mathrm{mg}$ of cholesterol and $30.0 \pm 0.2 \mathrm{mg}$ of proteins $/ \mathrm{mg}$ of DNA, $n=18$ ). This might indicate a decrease in ileal enterocyte size. Moreover, the cholesterol or protein/DNA ratio did not vary systematically with the site of the enterocyte on the villus. Consequently, a comparative study of cholesterol specific activity (dpm/mg of cholesterol) in the different cellular fractions should lead to the same results as those obtained with the radioactivity expressed in relation to each cell (dpm/mg of DNA).

The specific radioactivity of cholesterol from the different enterocytes $70 \mathrm{~min}$ after precursor administration is given in table 2 . At that time, the specific activity of plasma cholesterol was 50-100 times lower than that of cholesterol in the duodenal crypt cells. Whatever the collection site, the specific activity of cholesterol in crypt cells was higher than that in apical cells, with a decreasing gradient observed from the crypts to the top of the villi. It is noteworthy that this gradient was more pronounced in the distal ileum than in the first quarter of the small intestine. At the same time, we observed that the highest incorporation of cholesterol precursor occurred in the crypt cells of the proximal intestine (1st and 2nd quarters). Whereas the decreasing gradient of cholesterol specific activity from the crypts to the villi disappeared at all levels after $48 \mathrm{~h}$ (fig. 2), we observed

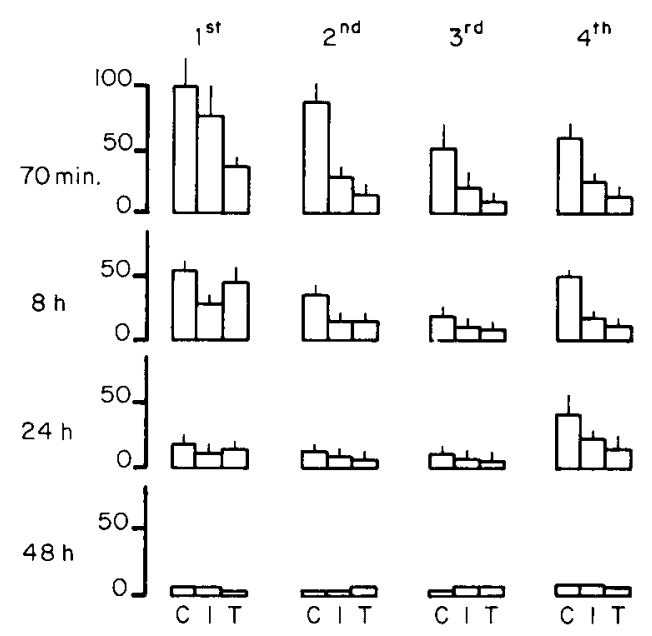

FIG. 2. - Profile of sterol specific activity in the enterocytes of rats (group A) receiving a subcutaneous injection of ${ }^{14} \mathrm{C}$-acetate. The cells were collected after the small intestine was divided into four equal quarters (1st, 2nd, 3rd, 4th).

C : crypt cells (fractions 7-9, Weiser's method) ; 1 : Intermediate cells (fractions 4-6, Weiser's method) ; $T$ : top cells (fractions 1-3, Weiser's method).

Mean \pm SEM. The values are the percentages of sterol specific activity in crypt duodenal cells of rats killed at $70 \mathrm{~min}$. 

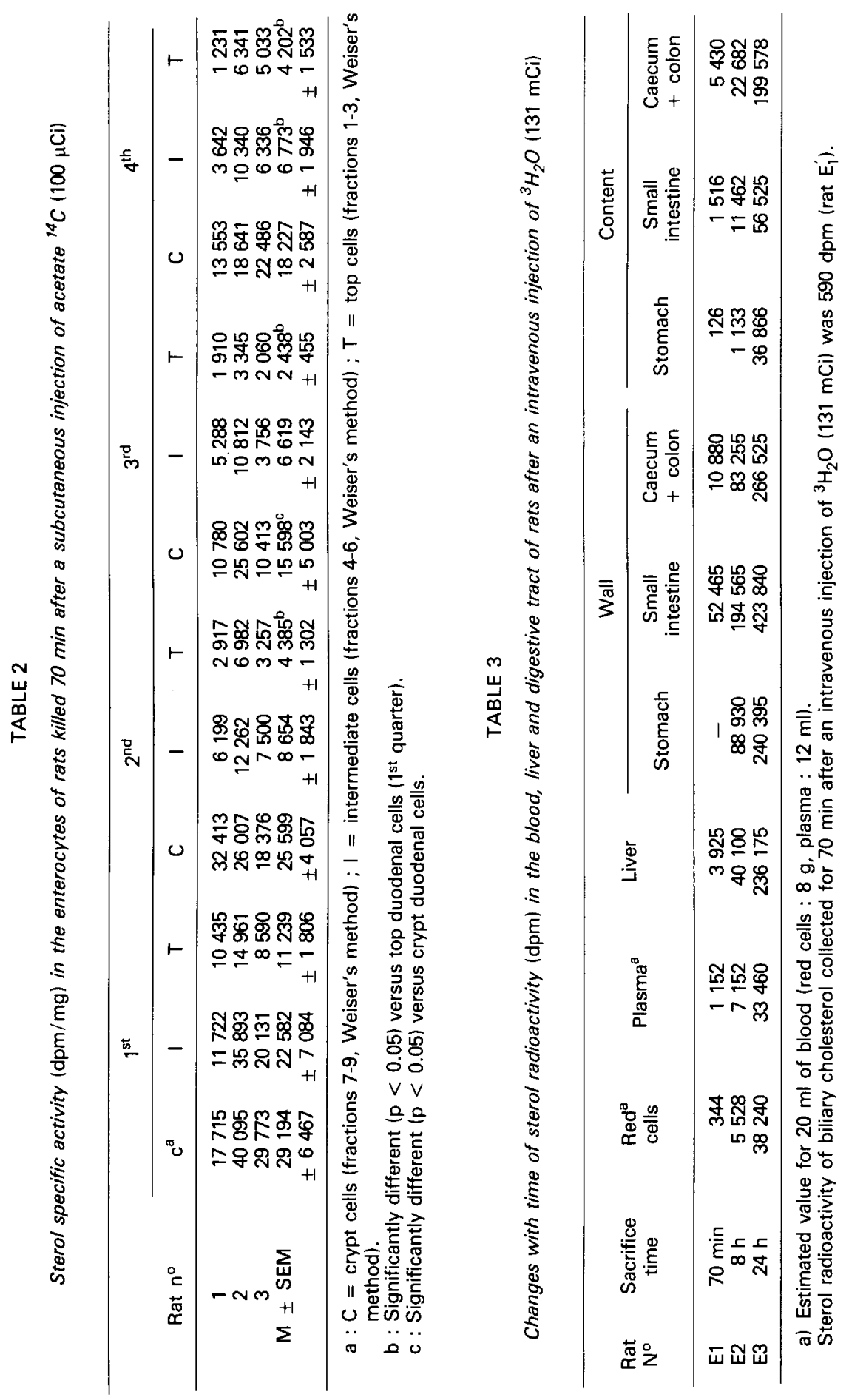
that the decrease in cholesterol specific activity in the crypts, a decrease reflecting its renewal, was faster in the first half of the intestine than in the second.

Experiment using " ${ }^{3} \mathrm{H}_{2} \mathrm{O}$ " (group E). - Sterol radioactivities measured in the blood, liver and main digestive organs of 3 rats given an intravenous injection of ${ }^{3} \mathrm{H}_{2} \mathrm{O}$ are listed in table 3 .

For the 70 min time, most of the radioactive cholesterol, as in the case of acetate, was found in the digestive tract and mainly in the small intestine. Twothirds of this radioactivity was located in the first half of the small intestine since the quarters of it contained 39, 25, 14 and $22 \%$, respectively, of intestinal sterol radioactivity in rat $E_{1}$. At that time, radioactivity was negligible in the bile cholesterol of rat $E_{1}^{\prime}$.

Figure 3 shows the specific radioactivity of cholesterol in the different enterocytes (expressed as a percent of that of cholesterol in the crypts of the 1st quarter) in rats $E_{1}$ and $E_{1}^{\prime}$ (with a biliary fistula) sacrificed $70 \mathrm{~min}$ after radioactive precursor injection. This figure shows a pattern similar to that observed after $\left[1-{ }^{14} \mathrm{C}\right]$-acetate injection.

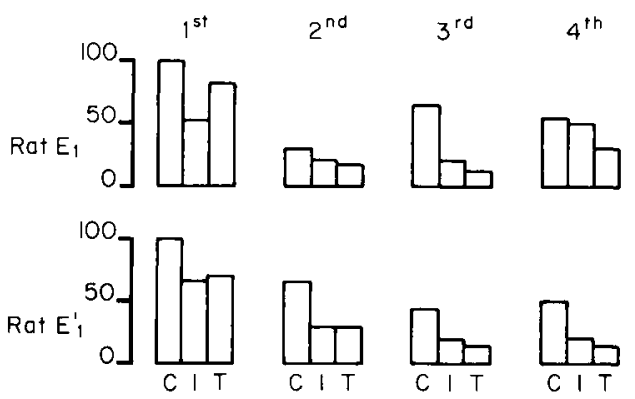

FIG. 3. - Sterol specific activity in the enterocytes of rats killed 70 min after intravenous injection of ${ }^{3} \mathrm{H}_{2} \mathrm{O}$.

The cells were collected after the small intestine was divided into four equal quarters (1st, 2nd, 3rd, 4th).

C : crypt cells ; I : intermediate cells ; T : top cells.

The values are the percentages of sterol specific activity in crypt duodenal cells. Top $=$ rat $E_{1}$; bottom = rat $E_{1}$ (see text).

\section{Discussion.}

The problem of the choice of a precursor, always present when measuring a biosynthetic rate of cholesterogenesis, has been debated for the last few years. Using $\left[1-{ }^{14} \mathrm{C}\right]$-octanoate, $\left[1-{ }^{14} \mathrm{C}\right]$-acetate and tritiated water, Stange and Dietschy (1983) compared in vivo and in vitro sterogenesis in parts of the intestine and in isolated cells. They estimated that $\left[1-{ }^{14} \mathrm{C}\right]$-acetate in vitro was a better substrate than $\left[1-{ }^{14} \mathrm{C}\right]$-octanoate and that the maximal rate of synthesis reached after an acetate injection represented 70 to $80 \%$ of that measured after tritiated water administration. Indeed, water crosses the cellular membrane very rapidly. Thus, water specific activity would be the same in every tissue (Andersen and Dietschy, 
1979). On the contrary, molecules such as acetate or octanoate cross the cellular and mitochondrial membrane more slowly, and may be diluted to various degrees. For these reasons, tritiated water was proposed by Stange and Dietschy as a better index of cholesterogenesis than substrates labelled with ${ }^{14} \mathrm{C}$. However, the use of tritiated water is difficult in vivo because whereas an intraperitoneal injection of $200 \mu \mathrm{Ci}\left[1-1{ }^{14} \mathrm{C}\right]$-acetate is sufficient to label cholesterol in rat enterocytes after $1 \mathrm{~h}, 100$ to $150 \mathrm{mCi}$ tritiated water are required to obtain a similar result. The manipulation of such a large quantity of radioactivity $\left(2-4 \times 10^{11} \mathrm{dpm}\right)$ requires special equipment and precautions. Moreover, an isotopic effect cannot be excluded with this light element (Chase and Rabinowitz, 1973). Finally, the number of tritium atoms incorporated by molecules of newly synthesized cholesterol may vary with the carbonate source of this sterol (Nilsson, 1975). We compared the results obtained in vivo with these two precursors: although the ${ }^{3} \mathrm{H}_{2} \mathrm{O}$ " experiment was restricted, certain conclusions can be drawn. At $70 \mathrm{~min}$, the results on changes in cholesterogenesis in the enterocytes along the intestine and in the villi were at least qualitatively comparable with the two isotopes. Under these conditions, acetate appears to be as good a qualitative index of in vivo cholesterogenesis as tritiated water. Moreover, if the location of cholesterogenesis in the intestine can be studied with tritiated water as well as with $\left[1-{ }^{14} \mathrm{C}\right]$-acetate, a turnover study of synthesized cholesterol is easier after labelling with $\left[1-{ }^{14} \mathrm{C}\right]$-acetate impulsion (see part II of this study). After intravenous administration of tritiated water, tissular water equilibrates rapidly (about $10 \mathrm{~min}$ ), reaching a plateau lasting for several hours (our results and those of Jeske and Dietschy, 1980). In fact, the turnover rate constant of body water is too low $\left(10 \%\right.$.day $\left.{ }^{-1}\right)$ for any significant variation in specific activity to be observed during a 24-hour experiment (Thomson, 1963). This was also true in the present experiment. Consequently, we obtained isotopic equilibrium of the radioactive precursor.

In such a study it is necessary to be sure that the radioactivity of the digitonin-precipitable sterols (measured in the digestive tract after a precursor injection) comes from in situ synthesis. Three facts showed that the possible contribution of labelled plasma cholesterol to in situ cholesterogenesis in the digestive tract was insignificant at $70 \mathrm{~min}$. (1) The specific activity of plasma cholesterol was 100 times lower than that of intestinal cholesterol at $70 \mathrm{~min}$ (group A rats). Moreover, cholesterol exchange between plasma and intestine was slow, i.e. less than $1 \%$ of cellular intestinal cholesterol exchange per hour with plasma cholesterol (Sérougne and Lutton, 1982); (2) at $70 \mathrm{~min}$, the cholesterol in the luminal content was very slightly labelled, that is, its radioactivity was not sufficient to significantly modify cholesterol radioactivity in the digestive tract ; (3) part of the luminal cholesterol was of biliary origin, i.e. it came from the liver. The collection of bile for $70 \mathrm{~min}$ from a rat fitted with a biliary fistula ( $r a t E_{1}^{\prime}$ ) showed that the radioactivity of biliary cholesterol was less than $2 \%$ that of intestinal cholesterol. Therefore, we concluded that cholesterol radioactivity in the gastrointestinal tract at $70 \mathrm{~min}$ reflected in situ cholesterogenesis.

After the administration of $\left[1-{ }^{14} \mathrm{C}\right]$-acetate or tritiated water, radioactive precursor incorporation by cholesterol was 5 to 8 times greater in the small 
intestine than in the stomach or the caecum plus colon. These results agree with previous observations and lead us to conclude that the intestine is the major site of cholesterogenesis in the rat digestive tract (Chevallier and Lutton, 1973), particularly in cholesterol-fed animals. Intestinal synthesis mainly (and perhaps solely) takes place in the mucosa and appears to be negligible (or zero) in the underlying muscular wall. This agrees with the previous conclusions of Dietschy and Siperstein (1965).

After $\left[1-{ }^{14} \mathrm{C}\right]$-acetate or tritiated water injection, precursor administration was 2 and 1.5 times higher, respectively, in the first half of the intestine (duodenum and jejunum) than in the second half (proximal and distal ileum) with a decreasing biosynthetic gradient from the duodenum to the distal ileum. These conclusions agree with those of Sugano et al. (1980) who used a semi-purified diet without cholesterol.

Whatever the radioactive precursor used or the part of the intestine studied, cholesterogenesis was 2 to 7 times higher in the crypt cells than in the apical cells with a decreasing gradient from the crypts to the top of the villi. The differences in synthetic activity between these two cellular fractions however were more pronounced in the distal ileum ( 4 times more with acetate) than in the duodenum (2.6 times more). Moreover cholesterogenesis was twice as high in the duodenal as in the ileal crypt cells. A similar profile of cholesterogenesis was observed in apical cells along the small intestine with a decreasing cholesterogenetic gradient from the duodenum to the ileum. These observations are not consistent with those of Merchant and Heller (1977) who found that in vivo and in vitro $\mathrm{HMGCoA}$ reductase activity and sterogenesis from $\left[1-{ }^{14} \mathrm{C}\right]$ acetate were 1.5 and 2 times higher in the cells from the top of the villi than in those from the crypts. Moreover, Mak and Trier (1972) using tritiated mevalonate incorporation into cholesterol and autoradiography, obtained results similar to those of Merchant. On the contrary, Muroya et al. (1977) observed in vivo and in vitro that acetate was incorporated into sterols as actively in the crypt as in the apical cells. Our results agree with those of Shefer et al. (1972) and Panini et al. (1979) who measured reductase activity in isolated intestinal cells and the in vivo and in vitro incorporation of acetate into digitonin-precipitable sterols (expressed or not per mg of proteins) of enterocytes. Moreover, Strandberg et al. (1981) recently showed that the steps of cholesterol biosynthesis between acetate and mevalonate, mevalonate and squalene, or squalene and cholesterol are more active in crypt cells than in apical cells. It is impossible to explain these conflicting observations by differences in the expression of the results. Indeed, the quantity of proteins and cholesterol in the enterocytes varies little with enterocyte localization on the villus (Sugano et al., 1980 ; Strandberg et al., 1981, present study). Furthermore, it was found that scraping the intestinal mucosa, a method commonly used to isolate crypt and apical cells, did not guarantee the purity of the cellular fractions collected. However, Merchant, using as we did the Weiser method, found higher cholesterol synthesis in the apical than in the crypt cells. According to him, this was due to differences in the acetate concentration between the two types of cells. Our similar results after acetate or tritiated water administration prove that even if there is appreciable acetate pool disparity 
between the enterocytes in relation to their location, it is not enough to reverse the results.

Sugano et al. (1980, 1982) observed a jejuno-ileal gradient of HMGCoA reductase activity in rats fed a pellet diet but not in those fed a semi-purified diet. Nevertheless, in the jejunum as in the ileum, enzyme activity was always higher in the crypts than at the top of the villi. This agrees with results obtained in the present study. Thus, all results are consistent with the idea that cholesterol synthesis is more active in the crypt cells, i.e. in cells undergoing intensive mitotic division, and that cholesterogenesis occurs in cells at the top of the villi, that is, in cells having no cellular division. Indeed, the existence of radioactive cholesterol in the latter cells, $70 \mathrm{~min}$ or $8 \mathrm{~h}$ after precursor administration, can hardly be explained by the intercellular movements of labelled cholesterol (see discussion in part II). Finally, this gradient is less marked in the duodenum than in the jejunum or ileum, suggesting that the modulation of cholesterogenesis varies with the part of the intestine considered. The mechanisms responsible for this modulation will be studied in a second article.

Reçu en décembre 1984. Accepté en avril 1985.

Acknowledgements. - The authors wish to thank M. Moqué for the illustrations and Mrs Boivin for typing the paper.

Résumé. Synthèse de cholestérol dans le tractus digestif du rat. I. Etude topologique.

Soixante-dix minutes après l'administration d'acétate $1-{ }^{14} \mathrm{C}$ ou d'eau tritiée à des rats ingérant un régime semi-synthétique contenant $0,5 \%$ de cholestérol, la radioactivité des stérols du tractus gastrointestinal a été mesurée. Les résultats sont qualitativement identiques avec les deux précurseurs. Ainsi, la synthèse de cholestérol, prépondérante dans l'intestin grêle, est localisée essentiellement dans sa muqueuse avec un gradient de biosynthèse décroissant du duodénum vers l'iléum distal. Un gradient de cholestérogenèse décroissant est également observé des cellules des cryptes vers les cellules du sommet des villosités, quelle que soit la portion d'intestin considérée.

\section{References}

ANDERSEN J. A., DIETSCHY J. M., 1979. Absolute rates of cholesterol biosynthesis in extrahepatic tissues with ${ }^{3} \mathrm{H}$-labeled water and ${ }^{14} \mathrm{C}$-labeled substrates. J. Lipid Res., 19, 740-752.

CHASE G. D., RABINOWITZ J. L., 1973. Isotopic tracers in biology, 455-490. In Principles of radioisotope methodology. Burgers Publ. Comp., Minneapolis.

CHEVALLIER F., LUTTON C., 1973. The intestine is the major site of cholesterol synthesis in the rat. Nature New Biol., 242, 61-62.

CHEVAlLiER F., SÉROUGNE C., CHAMPARNAUd G., 1975. Effect upon brain weight and cholesterol content of maintaining rats of various ages at constant weight. J. Nutr., 105 , 1003-1011.

CROFT D. N., LUBRAN M., 1975. The estimation of desoxyribonucleic acid in the presence of sialic acid : application to analysis of human gastric washings. J. Biochim., 95, 612-620. 
DIETSCHY J. M., SIPERSTEIN M. D., 1965. Cholesterol synthesis by the gastro-intestinal tract : Localization and mechanisms of control. J. clin. Invest., 44, 1311-1327.

GORNALL A. T., BARDAWILL C. J., DAVID M. M., 1949. Determination of serum proteins by means of the biuret reaction. J. biol. Chem., 177, 751.

JESKE D. J., DIETSCHY J. M., 1980. Regulation of rates of cholesterol synthesis in vivo in the liver and carcass of the rat measured using ${ }^{3} \mathrm{H}$ water. J. Lipid Res., 21, 364-376.

MAK K. M., TRIER J. S., 1972. Radioautographic and chemical evidence for $5{ }^{3} \mathrm{H}$ mevalonate incorporation into cholesterol by rat villous absorptive cells. Biochim. biophys. Acta, 280, 316-328.

MERCHANT J. L., HELLER R. A., 1977. 3-hydroxy-3-methyl-glutaryl-CoA reductase in isolated villous and crypt cells of rat ileum. J. Lipid Res., 18, 722-733.

MUROYA H., SODHI H. S., GOULD R. G., 1977. Sterol synthesis in intestinal villi and crypt cells of rats and guinea pigs. J. Lipid Res., 18, 301-308.

NILSSON A., 1975. Increased cholesterol-ester formation during forced cholesterol synthesis in rat hepatocytes. Eur. J. Biochem., 51, 337-342.

PANINI S. R., LEHRER G., ROGERS D. H., RUDNEY H., 1979. Distribution of 3-OH-3-methylglutaryl COA reductase and alkaline phosphatase activities in isolated epithelial cells of fed fasted, cholestyramine fed and 4-aminopyrazolo (3,4-d) pyrimidine treated rats. J. Lipid Res., 20, 879-889.

SÉROUGNE C., LUTTON C., 1982. Répartition du cholestérol d'origine plasmatique dans la villosité intestinale chez le rat. J. Physiol., Paris, 78, 170-174.

SHEFER S., HAUSER S., LAPAR V., MOSBACH E. H., 1972. HMG COA reductase of intestinal mucosa and liver of the rat. J. Lipid Res., 13, 402-412.

SPERRY W. M., WEBB M., 1950. A revision of the Schoenheimer-Sperry method for cholesterol determination. J. biol. Chem., 187, 97-106.

STANGE E. F., DIETSCHY J. M., 1983. Absolute rates of cholesterol synthesis in rat intestine in vitro and in vivo: a comparison of different substrates in slices and isolated cells. J. Lipid Res., 24, 72-82.

STRANDBERG T. E., TILVIS R. S., MIETTINEN T. A., 1981. Squalene and sterol synthesis in isolated small intestinal cells of the rat. Scand. J. Gastroenterol., 16, 801-810.

SUGANO M., FUJISAKI Y., OKU H., IDE T., 1982. 3-OH-3-methylglutaryl CoA reductase activity in the small intestine of rats fed non-purified and semipurified diets. J. Nutr., 112, 51-59.

SUGANO M., IDE T., OKAMATSU H., FUJISAKI Y., TAKAHARA H., 1980. Dietary modification of the distribution of 3-OH-3-methyl-glutaryl-COA and sterol-synthesizing activities in the rat small intestine. J. Nutr., 110, 360-370.

THOMSON J. F., 1963. Effects of $\mathrm{D}_{2} \mathrm{O}$ in mammals, 85-112. In ALEXANDER P., BACO Z. M., Biological effects of deuterium. Pergamon Press (Oxford, London, N.Y. Paris).

WEISER M. M., 1973. Intestinal epithelial cell surface membrane glycoprotein synthesis. An indication of cellular differentiation. J. biol. Chem., 248, 2536-2541. 